\title{
Journal of cotton research: a new platform for cotton science exchange and communication
}

\section{Fuguang}

Journal of Cotton Research (JCR) represents a brand new start of a scientific forum to advance cotton research communication. JCR is affiliated with Institute of Cotton Research of Chinese Academy of Agricultural Sciences (ICR, CAAS) and China Association of Agricultural Science Societies (CAASS), benefiting from solid academic support. In partnership with the leading Open Access brand BMC (part of Springer Nature), JCR aims to provide quality open access publishing service to the community.

The launch of JCR is not possible without many people's contribution. With joint effort of editorial board members and editorial office staff, we are fully committed to publish fine articles in JCR, which will be a valuable source for both researchers and readers worldwide in cotton science.

\section{The objective of launching JCR}

Past experience suggests that science- and technology-related improvements will further develop the cotton industry, which has been experiencing fluctuations in recent decades mainly owing to the unsettled world economy. Consequently, many fields of cotton research need to be more thoroughly investigated and we see breakthroughs happening in fields like genomics and bioinformatics, emerge. For example, a Cotton Genome Project was initiated by the Institute of Cotton Research of Chinese Academy of Agricultural Sciences (ICR, CAAS) in cooperation with BGI-China (ICR, CAAS, State Key Laboratory of Cotton Biology 2018). The publication of genomes of Gossypium raimondii, G. arboreum, G. hirsutum and G. barbadense (Wang et al. 2012; Li et al. 2014; Li et al. 2015; Zhang et al. 2015; Yuan et al. 2015), and the resequencing of upland cotton and G. arboreum (Du et al. 2018; Ma et al. 2018), have been achieved. These cotton whole-genome

Correspondence: lifuguang@caas.cn

Institute of Cotton Research, CAAS, Anyang, China sequencing projects have helped to forward genomics research, especially for the genetic improvement and evolutionary study of cotton. Thus, cotton researchers have many advances to share and many ideas to discuss. As a brand-new, open access journal, JCR will publish cutting-edge research, especially on genetics and genomics, abiotic and biotic stresses tolerance/resistance, and seed and fiber improvements. All articles will be published online immediately upon acceptance (after peer review).

JCR is preparing the following thematic series:

- Quantitative trait loci/genes related to fiber quality, yield or pest-resistance from different Gossypium species.

- Comparative functional/structural genomics of Gossypium arboreum, G. hirsutum and G. barbadense.

Each series will be conducted and supervised by one or more of the editorial board members (https://jcottonres.biomedcentral.com/about/editorial-board).

\section{We are publishing a few interesting articles to mark the journal launch}

Wang et al. have provided a summary of the relationships and diversity among species of the Gossypium genus, as well as the designations for individual genomes and chromosomes in Gossypium in Designations for individual genomes and chromosomes in Gossypium. The genus was divided into eight diploid genomic groups (A through G, and K), as well as one allopolyploid clade (AD genome), formed from mergers and chromosomal doubling in the A and D genomic ancestors millions years ago. This cytogenetic and genomic nomenclature will facilitate comparative genomic studies, basic taxonomic exploration, breeding and germplasm introgression.

In Genome-wide identification and expression analysis of Gossypium RING-H2 finger E3 ligase genes

(c) The Author(s). 2018 Open Access This article is distributed under the terms of the Creative Commons Attribution 4.0 International License (http://creativecommons.org/licenses/by/4.0/), which permits unrestricted use, distribution, and reproduction in any medium, provided you give appropriate credit to the original author(s) and the source, provide a link to the Creative Commons license, and indicate if changes were made. The Creative Commons Public Domain Dedication waiver (http://creativecommons.org/publicdomain/zero/1.0/) applies to the data made available in this article, unless otherwise stated. 
revealed their roles in fiber development, and phytohormone and abiotic stress responses, Qanmber et al. found that RING-H2 finger E3 ligase (RH2FE3) genes encode cysteine-rich proteins that mediate E3 ubiquitin ligase activity and degrade target substrates. $G$. hirsutum RH2FE3 genes strongly correlated with cotton fiber development. Additionally, most of the identified genes were up-regulated in response to Brassinolide, gibberellic acid, indole-3-acetic acid, salicylic acid and abiotic stresses. Thus, RH2FE3 genes play roles in cotton fiber development and respond to plant hormones and abiotic stresses.

Using $F_{2}$ segregated populations constructed using a short-branch cotton variety, X1570, crossed with a long-branch genotype, Ekangmian-13, to analyze the short-fruiting branch gene and marker-assisted selection with single nucleotide polymorphism (SNPs) linked to its traits, Zhang et al. identified a locus, SNP_GH1570, which is verified $100 \%$ co-segregated with short fruiting branch trait. This could be used for molecular-assisted selection to improve cotton architecture and help in cotton breeding and cultivation.

The planting of transgenic Bacillus thuringiensis (Bt) cotton is a major approach to control cotton bollworm. Lü et al. analyzed the effects of first-generation transgenic $B t$ cotton on the control of cotton bollworm in North China by investigating several parameters, including the number of cotton bollworms, the damage they inflicted to different cotton organs and the $B t$ protein content, in mainly cultivated cotton varieties from 2008 to 2015. Bt cotton varieties have been planted for more than 20 years in North China, and almost all $B t$ varieties are capable of controlling cotton bollworm effectively in North China.

We hope you enjoy reading the first series of articles. We also look forward to your submissions and feedback. The journal couldn't succeed without your continuous support.

\section{Publisher's Note}

Springer Nature remains neutral with regard to jurisdictional claims in published maps and institutional affiliations.

Received: 6 June 2018 Accepted: 6 June 2018

Published online: 29 June 2018

\section{References}

Du XM, Huang G, He SP, et al. Resequencing of 243 diploid cotton accessions based on an updated a genome identifies the genetic basis of key agronomic traits. Nat Genet. 2018;(2018-05-07) [2018-05-24]. https://doi.org/ 10.1038/s41588-018-0116-x.

Institute of Cotton Research of Chinese Academy of Agricultural Sciences, State Key Laboratory of Cotton Biology. Cotton genome project. 2018. http://cgp. genomics.org.cn/.

Li FG, Fan GY, Lu CR, et al. Genome sequence of cultivated upland cotton (Gossypium hirsutum TM-1) provides insights into genome evolution. Nat Biotechnol. 2015;33(5):524-30. https://doi.org/10.1038/nbt.3208.
Li FG, Fan GY, Wang KB, et al. Genome sequence of the cultivated cotton Gossypium arboreum. Nat Genet. 2014;46(6):567-72. https://doi.org/10.1038/ ng.2987.

Ma ZY, He SP, Wang XF, et al. Resequencing a core collection of upland cotton identifies genomic variation and loci influencing fiber quality and yield. Nat Genet. 2018;(2018-05-07) [2018-05-24]. https://doi.org/10.1038/s41588-0180119-7.

Wang KB, Wang ZW, Li FG, et al. The draft genome of a diploid cotton Gossypium raimondii. Nat Genet. 2012:44(10):1098-103. https://doi.org/10.1038/ng.2371.

Yuan DJ, Tang ZH, Wang MJ, et al. The genome sequence of sea-island cotton (Gossypium barbadense) provides insights into the allopolyploidization and development of superior spinnable fibres. Sci Rep. 2015;5(6):17662. https:// doi.org/10.1038/srep17662.

Zhang TZ, Hu Y, Jiang WK, et al. Sequencing of allotetraploid cotton (Gossypium hirsutum L. acc. TM-1) provides a resource for fiber improvement. Nat Biotechnol. 2015;33(5):531-7. https://doi.org/10.1038/nbt.3207.

\section{Ready to submit your research? Choose BMC and benefit from:}

- fast, convenient online submission

- thorough peer review by experienced researchers in your field

- rapid publication on acceptance

- support for research data, including large and complex data types

- gold Open Access which fosters wider collaboration and increased citations

- maximum visibility for your research: over $100 \mathrm{M}$ website views per year

At BMC, research is always in progress.

Learn more biomedcentral.com/submissions 